\title{
Neurobiology and Genetics of Behavioral Addictions: A Brief Review
}

\author{
Davranışsal Bağımlılıkların Nörobiyolojisi ve Genetiği: Kısa Bir Gözden Geçirme
}

\author{
(1) Filiz IZCi' 1 , (1) Nazife Gamze USTA SAĞLAM ${ }^{1}$, (1) Mine ERGELEN ${ }^{1}$
}

${ }^{1}$ Erenköy Ruh ve Sinir Hastalıkları Eğitim ve Araştırma Hastanesi, İstanbul, Türkiye

\section{Abstract}

Among behavioral addictions gambling disorder, sex, digital game, exercise, food, shopping and work addictions are similar to substance addictions at many points, including disruption in functionality, tolerance and withdrawal, comorbid diseases, genetic background and neuronal mechanisms. While neurobiological studies of behavioral addictions are very recent, research on biochemical, radiologic, genetic and treatment related features of behavioral addictions have revealed strong neurobiological associations with alcohol and substance addictions. Most of the studies in the literature focused on gambling addiction and internet addiction, but it is shown that beside their differences, there is also similar neurobiological and structural alterations exist in other behavioral addictions. It is important to recognize and understand behavioral addictions with their genetic and neurobiological aspects, to increase awareness of these disorders, to handle the process better and to develop prevention and treatment strategies. In this article, we reviewed data on the neurobiological and genetic manifestations and associated neurobiological pathways of behavioral addictions that are beginning to gain more attention from clinicians and researchers.

Keywords: Gambling disorder, Internet addiction, Food addiction, Sex addiction, Exercise addiction, Compulsive buying

\section{Öz}

Kumar oynama bozukluğu, seks bağımlılığı, dijital oyun bağımlılığı, egzersiz bağımlılığı, internet bağımlılığı, yeme bağımlılığı, alışveriş bağımlılı̆̆ ve iș bağımlılı̆ı gibi davranışsal bağımlılıklar, ișlevsellikte bozulma, tolerans ve çekilme, eșlik eden hastalıklar, nöronal yolaklar ve genetik arka plan dahil olmak üzere birçok noktada madde bağımlılıklarına benzemektedir. Bu alandaki nörobiyolojik araştırmalar henüz yeni olmakla birlikte, davranışsal bağımlılıklar biyokimyasal, radyolojik ve genetik özellikler açısından ele alındığında, madde kullanım bozuklukları ile güçlü nörobiyolojik ilişkiler ortaya çıkarmıştır. Literatürdeki çalışmaların çoğu kumar bağımlılığı ve internet bağımlılığı üzerine odaklanmış ancak diğer davranışsal bağımlılıkların da farklılıklarının yanı sıra benzer bazı yapısal değişikliklere de sahip oldukları gösterilmiștir. Davranışsal bağımlılıkları genetik ve nörobiyolojik yönleriyle tanımak ve anlamak, bu bozukluklara ilişkin farkındalığı artırmak, süreci daha iyi ele almak, önleme ve tedavi stratejileri geliștirmek açısından önemlidir. Bu yazıda, klinisyenler ve araștırmacılar tarafından son yıllarda daha fazla ilgi görmeye başlayan davranışsal bağımlııkların nörobiyolojik ve genetik özellikleri ve ilişkili nörobiyolojik yolaklara ilişkin verileri gözden geçirmeyi amaçladık.

Anahtar kelimeler: Kumar oynama bozukluğu, internet bağımlılığı, yeme bağımlılığı, seks băgımlılığı, egzersiz bağımlılığı, kompulsif satın alma

\section{Introduction}

Addiction is defined as a "habitual impulse" to engage in a specific activity or drug abuse, which has undesirable results on an individual's psychologic and physical health, social and financial status (1). The concept of behavioral addiction, on the other hand, includes an uncontrollable desire to exhibit a certain behavior and repeated pleasurable behavioral patterns, although it harms the individual's life $(2,3)$. Behavioral addictions such as gambling disorder (GD), sex, digital game, exercise, internet, food, work and shopping addictions (compulsive buying) have become important public health problems. Among these disorders, only GD is classified in DSM -5, but other behavioral addictions have started to be encountered frequently in the psychiatric practice (4). 
Addictive drugs that are rewarding in nature reinforce dopamine (DA) system in the brain and increase DA release in the nucleus accumbens (NAC) which is an important part of reward neurocircuits along with the extended amygdala, hippocampus, ventral tegmental area (VTA), ventral striatum, mesolimbic dopaminergic pathway, and prefrontal cortex $(5,6)$. DA is the most important neurotransmitter of this reward system. According to the reward deficiency hypothesis individuals who do not acquire enough satiety with natural rewards (water, food, sexuality) gravitate towards substances and behaviors to activate the reward pathway. DA receptor insufficiency creates a marked predisposition to impulsive and compulsive behaviors, alcohol and substance addiction, pathological gambling and addictive behaviors. Also, increased sensitivity to rewarding and reward seeking behaviors occurs. For example; internet use mimics the stimulation caused by alcohol and other substances with becoming a rapid reward with a short delay and providing more reward seeking and behavioral motivation (7).

Although neurobiological studies of behavioral addictions are relatively more recent than substance addiction researches, strong neurobiological associations has been demonstrated by biochemical, radioimaging, genetic and treatment studies between these disorders (8). Compulsive repetition of a problematic behavior, an appetizing impulse or urge before engaging in this act, diminished self-control, and a hedonic feature during the behavior are common key clinical features of behavioral and substance addictions (9). In addition, substance use disorders may often coexist with behavioral addictions. Comorbidity rates of gambling disorder with nicotine addiction have been reported as 70\%, with alcohol addiction as $50-75 \%$ and with other substances this rate approaches $40 \%$ (10-13). In this review, we aimed to address the neurobiological and genetic aspects of behavioral addictions.

\section{Gambling Disorder}

Gambling disorder (GD) can be described as insistent, repetitive and uncontrolled gambling in a way that impairs psychosocial functionality (4). While the pathophysiology of GD has not been completely understood, there is broad concurrence that several phenotypes are involved such as; increased impulsivity, risky decision making, sensory seeking, compulsivity and reward sensitivity and also cognitive distortions $(14,15)$.

\section{Neurotransmitters}

Stimulation of the DA transmission by drugs is a core feature of the reward system (16). While DA seems to be important in learning, motivation, emphasis and reward and lost processes, its role in GD continues to be investigated $(17,18)$. Recent data assert that the differentiation of stimuli from D2, D3 and D4 receptors may explain the role of DA in the pathophysiology of
GD (19,20). 5-HT metabolite levels (5-hydroxindolacetic acid (5HIAA)) in cerebrospinal fluid was found to be decreased in GD, and dysregulation in serotonergic functions in gamblers may be associated with impulsivity and inhibition of behavior (2123). The decrease in platelet monoamine oxidase (MAO) activity, which is an indicator of biological susceptibility for impulsivity, is another evidence for serotonergic dysfunction in GD (24-26), Serotonin $1 \mathrm{~B}$ receptor is also related with $\mathrm{GD}$ severity $(27,28)$.

\section{Neuroimaging}

Neuroimaging studies have shown dysfunctionalities in different areas of the brain in GD, although they focus especially on frontal and striatal zones (29-31). Among GDs both an increase and a decrease in ventromedial prefrontal cortex (VmPFC) activity have been reported during gambling and decision-making tasks compared to control group (32-36). Deterioration in frontal lobe function has been reported in patients with GD, and gambling behavior can be seen in patients with bilateral vmPFC lesions. $(37,38)$. Steady diversions in key node in neural circuit, including striatum, medial prefrontal cortex, amygdala, and insula have observed shown by functional magnetic resonance imaging (fMRI) during reward processing and decision-making tasks in patients with GD. Nevertheless, several studies have shown hypoactivity of this system while others have shown hyperactivity (32,39-41).

\section{Genetics}

In twin studies, it has been shown that genetic factors contribute more than environmental factors in the development of GD, and the prevalence of GD in first-degree relatives of individuals with GD was found to be $20 \%$ (42-45). These studies also revealed common genetic risk factors for GD and alcohol abuse (46).

An increase in A1 allele at the D2 receptor of DA (DRD2) locus was found in gamblers (47). Genetic polymorphisms related to DA transmission was shown to be related with irregular gambling $(48,49)$. Other studies highlights allelic variants such as; 5HTTLPR and MAO-A in 5-HT transmission genes in GD $(50,51)$. Also, polymorphisms in several genes, including DRD3, DRD4, HTR2A, and COMT have been shown in patients with GD (25,50,52-55).

\section{Internet Addiction}

Internet addiction is defined as having difficulty to control the use of the internet, spending more time on the internet, the loss of importance of time spent without using the internet, the emergence of excessive irritability, tension, anxiety when couldn't access internet and deterioration in the individual's work, social and family life (56).

\section{Neurotransmitters}

In internet addiction disorder (IAD) autonomic nervous system 
(ANS) is activated, heart rate and breathing accelerate and peripheral temperature decreases (57). Serum cortisol levels were found to be considerably high in adolescents with IAD (58). A decrease in plasma catecholamine levels such as; adrenaline and noradrenaline can be seen in adolescents with online game addiction at resting state (59). The peripheral blood DA levels are related to IAD in adolescents. (60). Increased anxiety and low peripheral blood norepinephrine levels was found to be associated with IAD (61).

\section{Neuroimaging}

Many imaging studies have shown some important changes in neural structure in IAD, mainly reduction in gray matter volume and changes in white-matter density (62). IAD was also found to be associated with thickening of the left anterior central cortex, middle frontal cortex, middle temporal cortex, infratemporal cortex, as well as slimming of the left lateral orbitofrontal cortex, insular cortex and entorhinal cortex $(63,64)$. Strengthening functional connections between the bilateral posterior lobes of the cerebellum and the middle temporal gyrus, but also, weakening of the connections between the bilateral lower parietal lobes and the right lower temporal gyrus have been reported (65).

Glucose metabolism decreases in the prefrontal and temporal cortexes and limbic systems, and also dysregulation of D2 receptors in the striatum have been observed in digital gamers as a result of overuse for many years (66). Money making activates orbitofrontal cortex and losses decrease the activation of cingulate cortex in internet addicts (67).

In a PET study by Kim et al., researchers have shown a decrease in DA D2 receptor levels in the caudate nucleus and putamen regions, in adult males with internet addiction (68). Likewise, reduced dopamine transporter levels in the striatum have been demonstrated in a single photon emission computed tomography (SPECT) study in internet addicts (69). In fMRI studies, activation of right prefrontal cortex, right NAC, medial frontal cortex and right caudate nucleus was observed while showing game pictures and paired images to individuals with internet gaming addiction (70-73). Resting state cerebral perfusion in parahippocampal gyrus, amygdala and insula is also found substantially high (74).

In conclusion, structural and functional alterations mainly in the orbitofrontal cortex, dorsolateral prefrontal cortex, anterior cingulate cortex, and posterior cingulate cortex were observed IAD (75). These brain regions are especially associated with reward, motivation, memory, and cognitive control.

\section{Genetics}

There are a few studies on the genetics of IAD. It has been shown that the genetic transition of internet addiction is around 48$66 \%$ when unshared environmental factors are excluded (76).
In a Korean study, excessive internet users was found to have a higher frequency of homozygous short allelic variant of the 5-HT transporter gene as in patients with major depression and also genetic and personality traits were found similar (77). Polymorphism in the nicotinic acetylcholine receptor gene is significantly frequent in internet addicts (78).

\section{Food Addiction}

Food addiction (FA) is defined as the frequent and abnormal consumption of some "extremely tasty" foods rich in high calories and glucose and the difficulty of controlling eating behavior (79). Repeated binge eating periods, increased binge eating after relative restriction of eating, loss of control overeating, consuming high-calorie foods, negative affect, and emotional lability are recommended criteria for FA, although there is no consensus (80).

\section{Neurotransmitters}

Natural rewarding stimuli such as water and food are also associated with significant synaptic changes in the mesolimbic DA system, as similar with the rewarding effects of psychostimulants and other abusive drugs $(81,82)$. Recent evidence suggests that compulsive eating behaviors and obesity influence the brain's reward circuit, particularly circuits of dopaminergic neural substrates as in substance use disorder. Increasing genetic and imaging data on addiction has indicated that obese individuals and substance addicts can show alterations in expression of DA D2 receptors in certain brain regions which can be stimulated by food and drugs (83).

In a study showing that striatal DA D2 receptors were significantly low in obese individuals compared to healthy controls, and body mass index (BMI) and D2 receptors were negatively correlated, it has been suggested that obese individuals continue pathological eating to compensate for DA deficiency and decrease in activation of motivation and reward circuits (84).

In obese mice down-regulation of striatal DA D2 receptors has been found similar to individuals with substance use disorder. Moreover, in rats with access to delicious high-fat foods, lentivirusmediated destruction of striatal DA D2 receptors was found to accelerate compulsive foraging and the development of reward deficits as in addiction disorders. These data assert that excessive consumption of tasty food triggers neuroadaptive reactions as in addiction and compulsive eating, FA and substance addiction may share common hedonic mechanisms (85).

\section{Neuroimaging}

The ventromedial prefrontal cortex, ventral striatum, amygdala, anterior insula, and mediodorsal thalamus are responsible for monetary, sexual and eating habits (86). Hippocampus which is found to be associated with obesity is stimulated by craving, 
hunger, and tasting $(87,88)$. Reduced DA D2 receptor activity in ventral striatum have identified in PET studies and also food addiction is found to be partially associated wih ventral striatum activity (5) (89).

\section{Genetics}

Reduced DA D2 receptor density have been found in individuals with A1 allele as in addiction disorders and obesity and a relatively high degree of reward sensitivity has been detected in obese patients carrying the A1 allele (90). In a study showing multilocus polymorphism of the DA D2 receptor gene and the mu-opioid receptor (OPRM1) gene, it was emphasized that individuals with binge eating disorder had higher scores in hedonic eating scales, and binge eating disorder is a biologically based obesity subtype (91).

\section{Sex Addiction/Compulsive Sexual Behaviour}

Sexual addiction (SA), that is also named as sexual impulsivity or hypersexuality, is expressed by abnormal sexual desire, urge or behaviors and having difficulty to control these drives and behaviors. $(92,93)$. The major symptoms are compulsive masturbation, excessive use of pornography or sexual webcam, repetitive seeking behavior of different sexual partner, and/or compulsive sex with a constant partner $(94,95)$.

Although there is no consensus on the conceptualization of SA, extensive criteria used to identify the disorder includes (a) increased time and effort devoted to sexual activity; (b) destruction of self-control; (c) spending less time on responsibilities; and (d) persistence in these sexual acts despite the negative outcomes. Tolerance, withdrawal and craving are common symptoms for SA and other addiction disorders $(96,97)$.

\section{Neurotrasmitters}

Preliminary results show that dopamine might contribute to the pathogenesis of compulsive sexual behavior (CSB). Dopamine agonists and other DA replacement therapies that used in Parkinson's disease (PD), increase the risk of having CSB (98). Naltrexone as an opioid antagonist has been found to be effective in alleviating excessive sexual impulses and behaviors, which is consistent with potential opioidergic alterations of mesolimbic DA function (99). Results of a study in which citalopram was superior to placebo in the treatment of CSB in homosexual men supports serotonergic dysfunction in CSB (91).

\section{Neuroimaging}

In a diffusion tension imaging study mean diffusivity of superior frontal region was found considerably high in patients with CSB compared to controls (100). Activation of the dorsal anterior cingulate, amygdala, and also ventral striatum have shown by fMRI in CSB patients by sexual stimuli (101). Exposure to pornographic cues has been found to increase the sexual desire in PD patients with hypersexuality, and activate the ventral striatum, cingulate cortex and orbitofrontal cortex (102). Increased time spent watching pornography among healthy men has been associated with left putaminal activity (103).

Subjects with CSB have shown higher amplitudes of the P300 response in attention control when subjected to sexual images compared to neutral images. (104). In a study evaluating responses to sexually stimuli, sexual desire was found to be associated with dorsal anterior cingulate activity, and substantia nigra activity increased in patients with CSB as a result of dopaminergic activity (101).

While erotic rewards and food have been associated with the anterior insular activity, amygdala activity was found to be more specifically related to erotic rewards. A recent study showed that the longer consumption of pornography was associated with left putaminal activity in healthy men (103). When hypersexuality is observed in behavioral variant frontotemporal dementia, the right ventral putamen and pallidum atrophy can be seen in correlation with reward seeking scores (105). In addition, in a case report of CSB, a partial increase in blood flow in the mesial temporal regions was observed on SPECT images (106).

\section{Genetics}

Limited evidence suggests that the majority of subjects with CSB had first-degree relatives with CSB or substance use disorder (107). It has been found that DA D2 receptor allele was found to be associated with first sexual intercourse age, and a stronger relationship observed when the DA D2 receptor interacted with the DA D1 receptor. (108). Specifically, across all ethnicities, polymorphism analyzes in DA D4 receptor have shown that age of first sexual intercourse is higher in those with any - 3R genotype than any other (109). Human leukocyte antigen (HLA) alleles were analyzed in Klein level syndrome, which is often accompanied by hypersexuality, and a significant amount of immunoresponsive HLA-DQB1, DQB1 $\square$ 0602, was detected (110).

\section{Compulsive Buying/Shopping Addiction}

People often turn to compulsive purchases in order to cope with daily stresses and create a positive impact. Compulsive buying or shopping addiction is described as the repetitive and excessive purchase of unnecessary consumer products. Compulsive buyers often describe short-term satisfaction and mood alterations. But this behavior can often causes large debts, negative comments from social environment, guilt and psychological stress, resulting in negative effects on self-esteem and comfort of life $(111,112)$.

\section{Neurotransmitters}

There is an imbalance between overstimulated urge state and deterioration of frontal inhibition, and impairment in reward 
system. An exaggerated state of craving and urge is observed due to changes in DA systems which is related with reward and reinforcement. Endogenous opioids lead to alterations in impulse control through working on reward, pleasure, and pain. There is also a decrease in peripheral 5-HT markers due to insufficiency of 5-HT system, that results in disinhibition (8).

Addiction-like behaviors such as hoarding or compulsive buying may be associated with high stress levels and the cumulative effects of neurotransmitters genetic variants, particularly DA. Therefore, when outcomes of dopaminergic activation are unsatisfaying with agonist therapy, DA homeostasis can be targetted in treating these undesirable behaviors (113). Some reports suggest that hyperdopaminergic states are observed in impulsive hoarding behavior, such as shopping addiction, and the blockage of D2 receptors may improve the condition (114). In a study by Kelley and Stinus, it was shown that when 6-hydroxydopamine lesions were seen in mesolimbic DA neurons, the hoarding behavior disappeared in rats, and was restored when L-Dopa was administered (115). In compulsive shopping neurotransmitter activity was found to be low and positive results were obtained with citalopram treatment. These results suggested possible serotonergic dysfunction in compulsive shopping $(116,117)$.

\section{Neuroimaging}

Remarkable differences were found in fMRI in the activity of cortical and subcortical areas related to decision-making between compulsive buyers and the healthy controls (118). Evidence from neuroimaging studies shows that gain and loss are determined by different brain circuits; while the insula is activated by high prices before the decision of purchase, the mesial prefrontal cortex is deactivated, and product preference is related with the NAC (119).

Several different cognitive domains were shown to support a possible neurobiological overlap between other behavioral and substance addictions to shopping addiction. Compared to healthy controls, individuals with compulsive buying appear to have deterioration in spatial working memory, response inhibition and risk assessment during decision-making (120). In a case report with substance use disorder, the addition of a pro-dopamine compound $\mathrm{KB} 200 \mathrm{z}$ to the treatment regimen significantly reduced stacking and shopping behaviors (113).

\section{Genetics}

There is not much data in the literature regarding the genetic basis of compulsive buying. The psychiatric disease comorbidity is high in compulsive buyers and their first degree relatives than healthy controls (121). In a study consist of 21 patients diagnosed with compulsive buying, deletion of 44-base pair (bp) was found in the promoter region of 5-HT transporter gene (122).

\section{Exercise Addiction/Compulsive Exercise}

Exercise addiction is defined as having difficulty in controlling exercise habits, spending more time for exercising and increasing frequency and intensity of exercise, inability to fulfill responsibilities due to exercise and exercising instead of spending time with family and friends and having troubles in planning the social life, other interests due to daily exercise routine $(123,124)$.

\section{Neurotransmitters}

Dopamine release increases in the hypothalamus with continuous aerobic exercise and in the dorsal striatum with running, and exercise also increases norepinephrine in the hypothalamus $(125,126)$. It is known that endogenous opioid system is one of the key factors in addictive disorders. Desire to increase $\beta$-endorphin levels through excessive exercise might be a potential mechanism leading to exercise addiction (127). Human and animal tests have pointed that aerobic exercise can improve many aspects of cognition and performance (128). It has been claimed that physical activity improves brain functions and cognition, and thus have protective effects against the neurodegenerative diseases (129). Physical activity has constructive effects on learning and memory by increasing advanced adult hippocampal neurogenesis and synaptic plasticity (130). It was shown that the effect of voluntary exercise reduced the exploratory and aggressive behavior in the spontaneously hypertensive rats and a sudden break on exercise leads to withdrawal reaction (131). The frequently mentioned molecular mechanism underlying structural and functional recovery of the brain in exercising animals is stimulation of hippocampal neurogenesis and BDNF expression $(132,133)$. In addition, a dramatic increase in cell proliferation and cognitive functions has been detected $(134,135)$. Another study assert that glutamatergic system modulates hippocampal volume and function through physical activity, but the mechanisms underlying this condition have not been clearly identified (136).

\section{Neuroimaging}

Running was shown to mediate the expression of ionotropic glutamate receptors in the subdivisions of rat hippocampus and it was considered to alter synaptic activity of hippocampus and thus have behavioral consequences (137). The exercising rats had 18\% lower DA D1 receptor binding levels in the olfactory tubercle and 21\% lower in the nucleus accumulators, compared to sedentary rats. In line with these findings, it can be claimed that aerobic exercise may cause alterations in the mesolimbic pathway and so drug-seeking behavior will decrease (138). Apart from these studies, cell proliferation in the hippocampus, which was low in 'depressed' rats, increased after 5 weeks of running. Therefore, it has been stated that repression of cell proliferation in the hippocampus may predispose to depression and exercise 
can be an effective in treatment (139).

\section{Genetics}

It has been suggested that some rodents with a predisposition to addictive drugs may show different preferences in running wheel exercise in crossbreds (140). It was observed that Lewis rats prone to addiction, developed a higher running activity than Fischer rats when given free access to running wheels, and were able to run up to $10 \mathrm{~km} /$ day after two weeks (141). Genetic studies suggest that naturally rewarding stimuli such as exercise are also controlled by genes that control drug preference, and moreover, considering the antidepressant efficacy of running, genes are assumed to be responsible for the neurochemical effects of running. (142).

\section{Conclusion}

Neurobiological similarities between substance addiction and behavioral addictions are well known. In this paper, we reviewed both the structural and biological changes in the brain and genetic studies with current studies in behavioral addictions. The effects of 5-HT, DA, NA and opioid systems and especially the reward system is emphasized on pathophysiology of behavioral addictions in literature. Similar to substance addiction, cortical and subcortical areas such as prefrontal cortex, nucleus accumbens, ventral tegmental area, amygdala, and hippocampus are also affected in behavioral addictions. In addition, genetic studies show that behavioral addictions are associated with some similar gene regions, although there are not many. Although only pathological gambling is included in the DSM-5 among behavioral addictions, we think that understanding the neurobiology of behavioral addictions will be important to develop prevention and treatment strategies.

\section{References}

1. Young KS, Yue XD, Ying L. Prevalence estimates and etiologic models of Internet addiction. Internet addiction: A handbook and guide to evaluation and treatment. 2011:3-17.

2. Mann K, Kiefer F, Schellekens A, Dom G. Behavioural addictions: classification and consequences. Eur Psychiatry 2017; 44: 187-188.

3. Black DW. Behavioural addictions as a way to classify behaviours. Can J Psychiatry 2013; 58(5): 249-251.

4. American Psychiatric Association. Diagnostic and Statistical Manual of Mental Disorders (DSM-5 ${ }^{\circledR}$ ). Washington DC: American Psychiatric Pub, 2013.

5. Volkow ND, Wang G-J, Fowler JS, et al. Addiction: beyond dopamine reward circuitry. Proc Natl Acad Sci U S A 2011; 108(37): 15037-15042.

6. Hui M, Gang Z. The dopamine system and alcohol dependence. Shanghai Arch Psychiatry 2014; 26(2): 61.

7. Blum K, Cull JG, Braverman ER, Comings DE. Reward deficiency syndrome Am Sci 1996; 84(2): 132-145.

8. Grant JE, Brewer JA, Potenza MN. The neurobiology of substance and behavioral addictions. CNS Spectr 2006; 11(12): 924-930.

9. Yau MYH, Potenza MN. Gambling disorder and other behavioral addictions: recognition and treatment. Harv Rev Psychiatry 2015; 23(2): 134-146.

10. Crockford DN, el-Guebaly N. Psychiatric comorbidity in pathological gambling: a critical review. Can J Psychiatry 1998; 43(1): 43-50.

11. Cunningham-Williams RM, Cottler LB, Compton 3rd W, Spitznagel EL. Taking chances: problem gamblers and mental health disorders--results from the St. Louis Epidemiologic Catchment Area Study. Am J Public Health 1998; 88(7): 1093-1096.

12. Petry NM, Stinson FS, Grant BF. Comorbidity of DSM-IV pathological gambling and other psychiatric disorders: results from the National Epidemiologic Survey on Alcohol and Related Conditions. J Clin Psychiatry 2005; 66(5): 564574.

13. McCormick RA, Russo AM, Ramirez LF, Taber JI. Affective disorders among pathological gamblers seeking treatment. Am J Psychiatry 1984; 141(2): 215218.

14. Blaszczynski A. Pathological gambling and obsessive-compulsive spectrum disorders. Psychol Rep 1999; 84(1): 107-113.

15. Van Holst RJ, van den Brink W, Veltman DJ, Goudriaan AE. Brain imaging studies in pathological gambling. Curr Psychiatry Rep 2010; 12(5): 418-425.

16. Wise RA. Dopamine, learning and motivation. Nat Rev Neurosci 2004; 5(6): 483-494.

17. Koob GF, Volkow ND. Neurocircuitry of addiction. Neuropsychopharmacology 2010; 35(1): 217-238.

18. Potenza MN. How central is dopamine to pathological gambling or gambling disorder? Front Behav Neurosci 2013; 7: 206.

19. Boileau I, Payer D, Chugani B, et al. In vivo evidence for greater amphetamineinduced dopamine release in pathological gambling: a positron emission tomography study with [11 C]-(+)-PHNO. Mol Psychiatry 2014; 19(12): 13051313.

20. Cocker PJ, Le Foll B, Rogers RD, Winstanley CA. A selective role for dopamine D4 receptors in modulating reward expectancy in a rodent slot machine task. Biol Psychiatry 2014; 75(10): 817-824.

21. Linnet], Møller A, Peterson E, et al. Inverse association between dopaminergic neurotransmission and lowa Gambling Task performance in pathological gamblers and healthy controls. Scand J Psychol 2011; 52(1): 28-34.

22. Nordin C, Eklundh T. Altered CSF 5-HIAA disposition in pathologic male gamblers. CNS Spectr 1999; 4(12): 25-33.

23. Brewer JA, Potenza MN. The neurobiology and genetics of impulse control disorders: relationships to drug addictions. Biochem Pharmacol 2008; 75(1): 63-75.

24. Ibanez A, De Castro IP, Fernandez-Piqueras J, et al. Pathological gambling and DNA polymorphic markers at MAO-A and MAO-B genes. Mol Psychiatry 2000; 5(1): 105-109.

25. de Castro IP, Ibanez A, Saiz-Ruiz J, Fernandez-Piqueras J. Concurrent positive association between pathological gambling and functional DNA polymorphisms at the MAO-A and the 5-HT transporter genes. Mol Psychiatry 2002; 7(9): 927-928.

26. Blanco C, Orensanz-Muñoz L, Blanco-Jerez C, Saiz-Ruiz J. Pathological gambling and platelet MAO activity: a psychobiological study. Am J Psychiatry 1996; 153(1): 119-121.

27. Potenza MN, Walderhaug E, Henry S, et al. Serotonin $1 \mathrm{~B}$ receptor imaging in pathological gambling. World J Biol Psychiatry 2013; 14(2): 139-145.

28. Leeman RF, Potenza MN. Similarities and differences between pathological gambling and substance use disorders: a focus on impulsivity and compulsivity. Psychopharmacology 2012; 219(2): 469-490.

29. Cavedini P, Riboldi G, Keller R, et al. Frontal lobe dysfunction in pathological 
gambling patients. Biol Psychiatry 2002; 51(4): 334-341.

30. Dannon PN, Shoenfeld N, Rosenberg G, et al. Pathological gambling: an impulse control disorder? Measurement of impulsivity using neurocognitive tests. Isr Med Assoc J 2010; 12(4): 243-248.

31. Ren Y, Fang J, Lv J, et al. Assessing the effects of cocaine dependence and pathological gambling using group-wise sparse representation of natural stimulus FMRI data. Brain Imaging Behav 2017; 11(4): 1179-1191.

32. Reuter J, Raedler T, Rose M, et al. Pathological gambling is linked to reduced activation of the mesolimbic reward system. Nat Neurosci 2005; 8(2): 147148.

33. Balodis IM, Kober H, Worhunsky PD, et al. Diminished frontostriatal activity during processing of monetary rewards and losses in pathological gambling. Biol Psychiatry 2012; 71(8): 749-757.

34. Choi J-S, Shin Y-C, Jung WH, et al. Altered brain activity during reward anticipation in pathological gambling and obsessive-compulsive disorder. PLoS One. 2012; 7(9): e45938.

35. Tanabe J, Thompson L, Claus E, et al. Prefrontal cortex activity is reduced in gambling and nongambling substance users during decision-making. Hum Brain Mapp 2007; 28(12): 1276-1286.

36. Power Y, Goodyear B, Crockford D. Neural correlates of pathological gamblers preference for immediate rewards during the lowa Gambling Task: an fMRI study. J Gambl Stud 2012; 28(4): 623-636.

37. Potenza MN, Leung H-C, Blumberg HP, et al. An FMRI Stroop task study of ventromedial prefrontal cortical function in pathological gamblers. Am J Psychiatry 2003; 160(11): 1990-1994.

38. Balconi M, Finocchiaro R, Canavesio $\mathrm{Y}$, Messina R. Reward bias and lateralization in gambling behavior: behavioral activation system and alpha band analysis. Psychiatry Res 2014; 219(3): 570-576.

39. Leyton M, Vezina P. On cue: striatal ups and downs in addictions. Biol Psychiatry 2012; 72(10): e21-e22.

40. van Holst RJ, Veltman DJ, Büchel C, et al. Distorted expectancy coding in problem gambling: is the addictive in the anticipation? Biol Psychiatry 2012 71(8): 741-748.

41. Chase HW, Clark L. Gambling severity predicts midbrain response to nearmiss outcomes. J Neurosci 2010; 30(18): 6180-6187.

42. Nautiyal KM, Okuda M, Hen R, Blanco C. Gambling disorder: an integrative review of animal and human studies. Ann N Y Acad Sci 2017; 1394(1): 106127.

43. Blanco C, Myers J, Kendler K. Gambling, disordered gambling and their association with major depression and substance use: a web-based cohort and twin-sibling study. Psychol Med 2012; 42(3): 497-508.

44. Slutske WS, Ellingson JM, Richmond-Rakerd LS, et al. Shared genetic vulnerability for disordered gambling and alcohol use disorder in men and women: evidence from a national community-based Australian Twin Study. Twin Res Hum Genet 2013; 16(2): 525-534.

45. Eisen SA, Slutske WS, Lyons MJ, et al. The genetics of pathological gambling. Semin Clin Neuropsychiatry 2001; 6(3): 195-204.

46. Slutske WS, Zhu G, Meier MH, Martin NG. Genetic and environmental influences on disordered gambling in men and women. Arch Gen Psychiatry 2010; 67(6): 624-630.

47. Comings DE. Why different rules are required for polygenic inheritance: lessons from studies of the DRD2 gene. Alcohol 1998; 16(1): 61-70.

48. Comings DE, Rosenthal RJ, Lesieur HR, et al. A study of the dopamine D2 receptor gene in pathological gambling. Pharmacogenetics 1996; 6(3): 223234.

49. Lobo DS, Souza RP, Tong RP, et al. Association of functional variants in the dopamine D2-like receptors with risk for gambling behaviour in healthy
Caucasian subjects. Biol Psychol 2010; 85(1): 33-37.

50. Sullivan EV, Pfefferbaum A. Neurocircuitry in alcoholism: a substrate of disruption and repair. Psychopharmacology 2005; 180(4): 583-594.

51. de Castro IP, Ibánez A, Saiz-Ruiz J, Fernández-Piqueras J. Genetic contribution to pathological gambling: possible association between a functional DNA polymorphism at the serotonin transporter gene (5-HTT) and affected men. Pharmacogenet Genomics 1999; 9(3): 397-400.

52. Lobo DS, Aleksandrova L, Knight J, et al. Addiction-related genes in gambling disorders: new insights from parallel human and pre-clinical models. Mol Psychiatry 2015; 20(8): 1002-1010.

53. Comings DE, Gonzalez N, Wu S, et al. Studies of the 48 bp repeat polymorphism of the DRD4 gene in impulsive, compulsive, addictive behaviors: Tourette syndrome, ADHD, pathological gambling, and substance abuse. Am J Med Genet 1999; 88(4): 358-368.

54. Grant JE, Leppink EW, Redden SA, et al. COMT genotype, gambling activity, and cognition. J Psychiatr Res 2015; 68: 371-376.

55. Wilson D, da Silva Lobo DS, Tavares $\mathrm{H}$, et al. Family-based association analysis of serotonin genes in pathological gambling disorder: evidence of vulnerability risk in the 5HT-2A receptor gene. J Mol Neurosci 2013; 49(3): 550-553.

56. Young KS. Internet addiction: A new clinical phenomenon and its consequences. Am Behav Sci 2004; 48(4): 402-415.

57. Lu DW, Wang JW, Huang ACW. Differentiation of Internet addiction risk level based on autonomic nervous responses: the Internet-addiction hypothesis of autonomic activity. Cyberpsychol Behav Soc Netw 2010; 13(4): 371-378.

58. Kim EH, Kim NH. Comparison of stress level and HPA axis activity of internet game addiction vs. non-addiction in adolescents. J Korean Bio Nurs Sci 2013; 15(4): 173-183

59. Kim N, Hughes TL, Park CG, et al. Resting-state peripheral catecholamine and anxiety levels in korean male adolescents with internet game addiction. Cyberpsychol Behav Soc Netw 2016; 19(3): 202-208.

60. Liu M, Luo J. Relationship between peripheral blood dopamine level and internet addiction disorder in adolescents: a pilot study. Int J Clin Exp Med 2015; 8(6): 9943.

61. Zhang H-X, Jiang W-Q, Lin Z-G, et al. Comparison of psychological symptoms and serum levels of neurotransmitters in Shanghai adolescents with and without internet addiction disorder: a case-control study. PloS One 2013; 8(5): e63089.

62. Weinstein A, Lejoyeux M. Neurobiological mechanisms underlying internet gaming disorder. Dialogues Clin Neurosci 2020; 22(2): 113-126.

63. Yuan K, Cheng P, Dong T, et al. Cortical thickness abnormalities in late adolescence with online gaming addiction. PloS One 2013; 8(1): e53055.

64. Zhu Y, Zhang H, Tian M. Molecular and functional imaging of internet addiction. Biomed Res Int 2015; 2015: 378675.

65. Ding W-n, Sun J-h, Sun Y-w, et al. Altered default network resting-state functional connectivity in adolescents with Internet gaming addiction. Plos One 2013; 8(3): e59902.

66. Tian M, Chen Q, Zhang Y, et al. PET imaging reveals brain functional changes in internet gaming disorder. Eur J Nucl Med Mol Imaging 2014; 41(7): 13881397.

67. Dong G, Huang J, Du X. Enhanced reward sensitivity and decreased loss sensitivity in Internet addicts: an fMRI study during a guessing task. J Psychiatr Res 2011; 45(11): 1525-1529.

68. Kim SH, Baik S-H, Park CS, et al. Reduced striatal dopamine D2 receptors in people with Internet addiction. Neuroreport 2011; 22(8): 407-411.

69. Hou H, Jia S, Hu S, et al. Reduced striatal dopamine transporters in people 
with internet addiction disorder. J Biomed Biotechnol 2012; 2012: 854524.

70. Ko C-H, Liu G-C, Hsiao S, et al. Brain activities associated with gaming urge of online gaming addiction. J Psychiatr Res 2009; 43(7): 739-747.

71. Han DH, Kim YS, Lee YS, et al. Changes in cue-induced, prefrontal cortex activity with video-game play. Cyberpsychol Behav Soc Netw 2010; 13(6): 655-661.

72. Ko CH, Liu GC, Yen JY, et al. Brain correlates of craving for online gaming under cue exposure in subjects with internet gaming addiction and in remitted subjects. Addict Biol 2013; 18(3): 559-569.

73. Lorenz RC, Krüger JK, Neumann B, et al. Cue reactivity and its inhibition in pathological computer game players. Addiction Biol 2013; 18(1): 134-146.

74. Feng Q, Chen X, Sun J, et al. Voxel-level comparison of arterial spin-labeled perfusion magnetic resonance imaging in adolescents with internet gaming addiction. Behav Brain Funct 2013; 9(1): 33

75. Park B, Han DH, Roh S. Neurobiological findings related to internet use disorders. Psychiatry Clin Neurosci 2017; 71(7): 467-478.

76. Vink JM, Van Beijsterveldt TC, Huppertz C, et al. Heritability of compulsive internet use in adolescents. Addiction Biol 2016; 21(2): 460-468.

77. Lee YS, Han DH, Yang KC, et al. Depression like characteristics of 5HTTLPR polymorphism and temperament in excessive internet users. J Affect Disord 2008; 109(1-2): 165-169

78. Montag C, Kirsch P, Sauer C, et al. The role of the CHRNA4 gene in internet addiction: a case-control study. J Addict Med 2012; 6(3): 191-195.

79. Tuomisto T, Hetherington MM, Morris MF, et al. Psychological and physiological characteristics of sweet food "addiction". Int J Eat Disord 1999; 25(2): 169-175.

80. Çopur M, Tınkır NS. Yeme bağımlılı̆̆ı. Türkiye Klinikleri Çocuk PsikiyatrisiÖzel Konular 2020; 6(1): 47-53.

81. Schultz W. Updating dopamine reward signals. Curr Opin Neurobiol 2013; 23(2): 229-238.

82. Schultz W. Behavioral dopamine signals. Trends Neurosci 2007; 30(5): 203210.

83. Baik J-H. Dopamine signaling in food addiction: role of dopamine D2 receptors. BMB Rep 2013; 46(11): 519.

84. Wang G-J, Volkow ND, Logan J, et al. Brain dopamine and obesity. Lancet 2001; 357(9253): 354-357.

85. Johnson PM, Kenny PJ. Dopamine D2 receptors in addiction-like reward dysfunction and compulsive eating in obese rats. Nat Neurosci 2010; 13(5): 635 .

86. Sescousse G, Caldú X, Segura B, Dreher J-C. Processing of primary and secondary rewards: a quantitative meta-analysis and review of human functional neuroimaging studies. Neurosci Biobehav Rev 2013; 37(4): 681 696

87. Haase L, Cerf-Ducastel B, Murphy C. Cortical activation in response to pure taste stimuli during the physiological states of hunger and satiety Neuroimage 2009; 44(3): 1008-1021.

88. Bragulat V, Dzemidzic M, Bruno C, et al. Food-related odor probes of brain reward circuits during hunger: a pilot fMRI study. Obesity 2010; 18(8): 15661571.

89. Romer AL, Kang MS, Nikolova YS, et al. Dopamine genetic risk is related to food addiction and body mass through reduced reward-related ventral striatum activity. Appetite 2019; 133: 24-31.

90. Davis C, Levitan RD, Kaplan AS, et al. Reward sensitivity and the D2 dopamine receptor gene: A case-control study of binge eating disorder. Prog
Neuropsychopharmacol Biol Psychiatry 2008; 32(3): 620-628.

91. Davis CA, Levitan RD, Reid C, et al. Dopamine for "wanting" and opioids for "liking": a comparison of obese adults with and without binge eating. Obesity (Silver Spring) 2009; 17(6): 1220-1225.

92. Kafka MP. The development and evolution of the criteria for a newly proposed diagnosis for DSM-5: Hypersexual disorder. Sexual Addiction \& Compulsivity 2013; 20(1-2): 19-26.

93. Walters GD, Knight RA, Långström N. Is hypersexuality dimensional? Evidence for the DSM-5 from general population and clinical samples. Arch Sex Behav 2011; 40(6): 1309-1321.

94. Wéry A, Vogelaere K, Challet-Bouju G, et al. Characteristics of self-identified sexual addicts in a behavioral addiction outpatient clinic. J Behav Addict 2016; 5(4): 623-630.

95. Karila L, Wéry A, Weinstein A, et al. Sexual addiction or hypersexual disorder Different terms for the same problem? A review of the literature. Curr Pharm Des 2014; 20(25): 4012-4020.

96. Rosenberg KP, Carnes P, O'Connor S. Evaluation and treatment of sex addiction. J Sex Marital Ther 2014; 40(2): 77-91.

97. Allen A, Kannis-Dymand L, Katsikitis M. Problematic internet pornography use: The role of craving, desire thinking, and metacognition. Addict Behav 2017; 70: 65-71.

98. Weintraub D, Koester J, Potenza MN, et al. Impulse control disorders in Parkinson disease: a cross-sectional study of 3090 patients. Arch Neurol 2010; 67(5): 589-595.

99. Raymond NC, Grant JE, Coleman E. Augmentation with naltrexone to treat compulsive sexual behavior: a case series. Ann Clin Psychiatry 2010; 22(1): $56-62$

100. Miner MH, Raymond N, Mueller BA, et al. Preliminary investigation of the impulsive and neuroanatomical characteristics of compulsive sexual behavior. Psychiatry Res Neuroimaging 2009; 174(2): 146-151.

101. Voon V, Mole TB, Banca P, et al. Neural correlates of sexual cue reactivity in individuals with and without compulsive sexual behaviours. PLoS One 2014; 9(7): e102419.

102. Politis M, Loane C, Wu K, et al. Neural response to visual sexual cues in dopamine treatment-linked hypersexuality in Parkinson's disease. Brain 2013; 136(2): 400-411.

103. Kühn S, Gallinat J. Brain structure and functional connectivity associated with pornography consumption: the brain on porn. JAMA Psychiatry 2014; 71(7): 827-834.

104. Steele VR, Staley C, Fong T, Prause N. Sexual desire, not hypersexuality, is related to neurophysiological responses elicited by sexual images Socioaffect Neurosci Psychol 2013; 3(1): 20770.

105. Perry DC, Sturm VE, Seeley WW, et al. Anatomical correlates of rewardseeking behaviours in behavioural variant frontotemporal dementia. Brain 2014; 137(6): 1621-1626.

106. Kataoka H, Shinkai T, Inoue M, Satoshi U. Increased medial temporal blood flow in Parkinson's disease with pathological hypersexuality. Movement Disorders 2009; 24(3): 471-473.

107. Schneider J, Schneider B. Couple recovery from sexual addiction: research findings of a survey of 88 marriages. Sexual Addiction \& Compulsivity 1996; 3: $111-126$.

108. Miller WB, Pasta DJ, MacMurray J, et al. Dopamine receptor genes are associated with age at first sexual intercourse. J Biosoc Sci 1999; 31(1): 43 54.

109. Guo G, Tong Y. Age at first sexual intercourse, genes, and social context: 
Evidence from twins and the dopamine D4 receptor gene. Demography 2006; 43(4): 747-769.

110. Huang C-J, Liao H-T, Yeh G-C, Hung K-L. Distribution of HLA-DQB1 alleles in patients with Kleine-Levin syndrome. J Clin Neurosci 2012; 19(4): 628-630.

111. Mestre-Bach G, Steward T, Jiménez-Murcia S, Fernández-Aranda F. Differences and similarities between compulsive buying and other addictive behaviors. Curr Addict Rep 2017; 4(3): 228-236.

112. Zhang C, Brook JS, Leukefeld CG, et al. Compulsive buying and quality of life: An estimate of the monetary cost of compulsive buying among adults in early midlife. Psychiatry Res 2017; 252: 208-214.

113. McLaughlin T, Blum K, Steinberg B, et al. Pro-dopamine regulator, KB220Z, attenuates hoarding and shopping behavior in a female, diagnosed with SUD and ADHD. J Behav Addict 2018; 7(1): 192-203.

114. Borker A, Mascarenhas J. Role of acetylcholine and dopamine in dorsal hippocampus on hoarding behavior in rats. Indian J Physiol Pharmacol 1991; 35(1): 71-73.

115. Kelley AE, Stinus L. Disappearance of hoarding behavior after 6-hydroxydopamine lesions of the mesolimbic dopamine neurons and its reinstatement with \{l\}-dopa. Behav Neurosci 1985; 99(3): 531.

116. Koran LM, Bullock KD, Hartston HJ, et al. Citalopram treatment of compulsive shopping: an open-label study. J Clin Psychiatry 2002; 63(8): 704-708.

117. Koran LM, Chuong HW, Bullock KD, Smith SC. Citalopram for compulsive shopping disorder: an open-label study followed by double-blind discontinuation. J Clin Psychiatry 2003; 64(7): 793-798.

118. Raab G, Elger CE, Neuner M, Weber B. A neurological study of compulsive buying behaviour. J Consum Policy 2011; 34(4): 401.

119. Knutson B, Rick S, Wimmer GE, et al. Neural predictors of purchases. Neuron 2007; 53(1): 147-156.

120. Derbyshire KL, Chamberlain SR, Odlaug BL, et al. Neurocognitive functioning in compulsive buying disorder. Ann Clin Psychiatry 2014; 26(1): 57-63.

121. Black DW, Repertinger S, Gaffney GR, Gabel J. Family history and psychiatric comorbidity in persons with compulsive buying: preliminary findings. Am J Psychiatry 1998; 155(7): 960-963.

122. Devor EJ, Magee HJ, Dill-Devor RM, et al. Serotonin transporter gene (5-HTT) polymorphisms and compulsive buying. Am J Med Genet 1999; 88(2): 123125.

123. Adams J, Kirkby RJ. Excessive exercise as an addiction: A review. Addict Res Theory 2002; 10(5): 415-437.

124. Zmijewski CF, Howard MO. Exercise dependence and attitudes toward eating among young adults. Eat Behav 2003; 4(2): 181-195.

125. Herrera JJ, Fedynska S, Ghasem PR, et al. Neurochemical and behavioural indices of exercise reward are independent of exercise controllability. Eur J Neurosci 2016; 43(9): 1190-1202.

126. Hasegawa H, Takatsu S, Ishiwata $\mathrm{T}$, et al. Continuous monitoring of hypothalamic neurotransmitters and thermoregulatory responses in exercising rats. J Neurosci Methods 2011; 202(2): 119-123.

127. Trott M, Yang L, Jackson SE, et al. Prevalence and correlates of exercise addiction in the presence vs. absence of indicated eating disorders. Front Sports Act Living. 2020; 2: 84.

128. Hillman CH, Erickson KI, Kramer AF. Be smart, exercise your heart: exercise effects on brain and cognition. Nat Rev Neurosci 2008; 9(1): 58-65.

129. Kramer AF, Erickson KI. Capitalizing on cortical plasticity: influence of physical activity on cognition and brain function. Trends Cogn Sci 2007; 11(8): 342-348.

130. Vivar C, Potter MC, van Praag H. All about running: synaptic plasticity, growth factors and adult hippocampal neurogenesis. Curr Top Behav Neurosci 2013; 15: 189-210.

131. Hoffmann P, Thorén P, Ely D. Effect of voluntary exercise on open-field behavior and on aggression in the spontaneously hypertensive rat (SHR). Behav Neural Biol 1987; 47(3): 346-355.

132. Van Praag H, Shubert T, Zhao C, Gage FH. Exercise enhances learning and hippocampal neurogenesis in aged mice. J Neurosci 2005; 25(38): 86808685.

133. Yau SY, Gil-Mohapel J, Christie BR, So KF. Physical exercise-induced adult neurogenesis: a good strategy to prevent cognitive decline in neurodegenerative diseases Biomed Res Int 2014; 2014: 403120.

134. Van der Borght $K$, Havekes R, Bos $T$, et al. Exercise improves memory acquisition and retrieval in the $\mathrm{Y}$-maze task: relationship with hippocampal neurogenesis. Behav Neurosci 2007; 121(2): 324.

135. Merkley CM, Jian C, Mosa A, et al. Homeostatic regulation of adult hippocampal neurogenesis in aging rats: long-term effects of early exercise. Front Neurosci 2014; 8: 174.

136. Biedermann S, Fuss J, Zheng L, et al. In vivo voxel based morphometry: detection of increased hippocampal volume and decreased glutamate levels in exercising mice. Neuroimage 2012; 61(4): 1206-1212.

137. Staples MC, Somkuwar SS, Mandyam CD. Developmental effects of wheel running on hippocampal glutamate receptor expression in young and mature adult rats. Neuroscience 2015; 305: 248-256.

138. Robison LS, Swenson S, Hamilton J, Thanos PK. Exercise reduces dopamine D1R and increases D2R in rats: implications for addiction. Med Sci Sports Exerc 2018; 50(8): 1596-1602.

139. Bjørnebekk A, Mathé AA, Brené S. The antidepressant effect of running is associated with increased hippocampal cell proliferation. Int J Neuropsychopharmacol 2005; 8(3): 357-368.

140. Brené S, Bjørnebekk A, Åberg E, et al. Running is rewarding and antidepressive. Physiol Behav 2007; 92(1-2): 136-140.

141. Werme M, Thorén P, Olson L, Brené S. Addiction-prone Lewis but not Fischer rats develop compulsive running that coincides with downregulation of nerve growth factor inducible-B and neuron-derived orphan receptor 1. J Neurosci 1999; 19(14): 6169-6174.

142. Weinstein A, Weinstein Y. Exercise addiction-diagnosis, bio-psychological mechanisms and treatment issues. Curr Pharm Des 2014; 20(25): 4062 4069 . 